\title{
The Initial Years of Motherhood and Fatherhood as Perceived by Expectant Parents: The Division of Care and Paid Work ${ }^{1}$
}

\author{
Olga Nešporová
}

\begin{abstract}
This study provides an outline of plans and norms regarding the first years of fatherhood and motherhood and focuses on the division of care and paid work between Czech parents. It is based on 32 interviews conducted with expectant parents from dual-earner heterosexual couples. The ideals and plans of the expectant parents embedded in real life options were studied and analysed in order to identify various care models to be employed over the first three years of parenthood. In all three principal care models revealed by the study sample, the fathers continued to work full time while the plans of the mothers were more varied. The models were classified as 1) the long-term full-time mother care model, 2) the longterm part-time mother care model, and 3) the short-term mother care model. The intra-couple comparative analysis revealed common discrepancies between the plans of the partners regarding the employment of the mother and the use of non-parental childcare. Expectant fathers more often professed traditional conservative views than their female partners.
\end{abstract}

KEY WORDS Fatherhood, motherhood, Czech Republic, parenthood, work and childcare

\section{Introduction}

The everyday praxis of parenthood is strongly influenced by structural conditions as well as by attitudes and cultural/social norms concerning motherhood and fatherhood (Crompton and Harris 1998; Crompton and Lyonette 2005, 2011; Duncan and Erwin 2004). In the Czech context, structural conditions surrounding motherhood have been studied repeatedly, with particular attention being devoted to mothers of small children and the issue of reconciling the maternal role with paid employment (Bartáková 2005; Čermáková et al. 2002; Dudová 2008; Ettlerová et al. 2006; Kuchařová et al. 2006; Křŕžková et al. 2009; Křížková and Vohlídalová 2008, 2009; Křížková et al. 2011; Sokačová 2006). The topic of fatherhood, however, has been all but neglected. ${ }^{2}$ The limited number of studies which have focused solely or partly on fathers have tended to concentrate, in the main, on the different role they play based on a description of their limited participation in childcare and housework (Dudová

Sociálni studia / Social Studies 4/2016. Pp. 9-25. ISSN 1214-813X.

1 This study is a part of the research project 15-14736S "Fatherhood and Motherhood in the contexts of Labour Market and Social Policy" supported by the Czech Science Foundation (GA ČR).

2 A similar situation has been reported in Poland (Suwada and Plantin 2014). 
2006, 2008; Křížková 2006; Maříková and Vohlídalová 2007). A small number of studies have been carried out focusing on caring fathers and fathers opting to take parental leave, and the functioning of those families choosing to employ this model (Maříková 2008, 2009; Mař́ková and Vohlídalová 2007; Nešporová 2005, 2006; Šmídová 2004, 2009).

This study focuses on norms, a topic which has been very much neglected by Czech sociologists. Norms are essential since they create boundaries within which parents attempt to position themselves during the parenting period. The boundaries within which parents make their choices. Therefore, the determination of effective family policy which attempts to reconcile parenthood with employment requires this knowledge. It has been pointed out by a number of authors that parents do not act in an individualistic and economically rational way in terms of combining childcare and paid work and that moral and socially negotiated views about what is right and proper are of key importance in the decision-making process (Duncan and Edwards 1999; Duncan, Edwards and Alldred 2003; Duncan and Irwin 2004).

Norms are always embedded in a wider context and, therefore, it is important that the reader be provided with a certain amount of basic information regarding structural conditions. Czech family policy post 1989 can best be described as gendered and implicitly characterised by "familialism" (Saxonberg and Sirovátka 2006; Sirovátka 2004). Policy supported the traditional division of gender roles and encouraged mothers to leave the labour market to care for their children on a full-time basis for three (or even four) years. Most childcare facilities for young children were shut down during the 1990s; thus, only approximately $1 \%$ of children aged three years or younger have attended public childcare facilities since the early 2000s (Kuchařová and Svobodová 2006; Paloncyová et al. 2014). The situation has improved, albeit slowly, with half-hearted attempts to make use of the parental allowance more flexible (since 2008), and the withdrawal of limits on using childcare facilities while receiving the parental allowance (Nešporová 2015). On the other hand, the lack of public childcare facilities for children under three and, in some areas of the country, even older has been criticised repeatedly over the last decade or so (Hašková and Saxonberg 2012; Hašková and Uhde 2009; Kuchařová and Svobodová 2006; Paloncyová et al. 2013). Pre-school childcare facilities are commonly attended by children aged four and five, of whom around $90 \%$ are enrolled in such facilities. ${ }^{3}$ However, the attendance of younger children at childcare facilities is much less common in the Czech Republic. While around $60 \%$ of three-year-old children are enrolled at childcare facilities, only a minority (approximately $10 \%$ ) of younger children (under three years of age) attend such facilities (either public or private nurseries or kindergartens; this estimation is based on Kuchařová and Svobodová [2006: 10] and Hašková and Saxonberg [2012]).

Two principal family policy measures enable Czech parents to provide their children with long-term home care, namely maternity leave and parental leave. Nearly all those mothers eligible for such leave take advantage of 28 weeks of paid maternity leave. ${ }^{4}$

3 Most of those children (98 \%) attend the public kindergartens (Paloncyová et al. 2014: 19; data for years 2011-2014).

4 A parent on maternity leave is entitled to benefits at a level of $70 \%$ of their individual daily wage base (with upper limits). Paid maternity leave is not eligible for self-employed women who did not pay health insurance. 
The subsequent parental leave period, during which time the parental allowance can be claimed, can be taken either by the mother or by the father (since 2001), up to the child's third birthday. According to statistics on those who receive the parental allowance, men make up less than $2 \%$ of the total. ${ }^{5}$ The monthly amount of the allowance depends on the length of the period over which parents decide to claim; the shorter the claim period, the higher the monthly allowance. ${ }^{6}$ Under current legislation parents are not subject to any limits with regard to employment while on parental leave or whilst claiming the parental allowance, which is crucial in terms of ensuring that parents are able to maintain contact with the world of paid work.

Plans and expectations about division of care and paid work between parents after childbirth reveal much about cultural norms of motherhood and fatherhood. It has been proved by Miller's analysis of longitudinal qualitative data on the transition to motherhood that expectations of motherhood differ significantly from the real experience of motherhood and that the former are, to a great extent, shaped by cultural expectations (Miller 2007). The approach selected in my study is innovative in two ways. Firstly, it focuses on plans and norms which are considered to be the important "missing 'middle element' between the social ethics of family practices and theories of general social processes" (Duncan and Irwin 2004: 398). Secondly, both members of the parental couple were studied; i.e. in the search for plans concerning combining childcare with paid employment, the father's plans, values and opinions, which have to date been very much neglected, were also taken into account.

The study attempts to shed light on plans and norms concerning the parenting expectations of Czech middle-class heterosexual couples awaiting their first child. How do expectant mothers and fathers expect childcare to be divided between the mother, father and possibly other persons and institutions? Based on the analysis of 32 in-depth interviews about anticipated work and care arrangements, three main care models were identified. The cultural norm of (three years) full-time motherhood was not at all shared by expectant mothers. However, it is still very much expected in the context of institutional circumstances, as well as encouraged by the norm of intensive motherhood. Furthermore, intra-couple comparative analysis showed that expectant fathers more often professed traditional conservative views regarding reconciling parenthood with paid work more often than their female partners.

\section{Methodology}

The analysis is based on data gathered by means of qualitative research which aimed to investigate the attitudes of expectant mothers and fathers concerning approaching parenthood focusing particularly on the division of labour and care between the parents and combining

Source: Ministry of Labour and Social Affairs; http://www.mpsv.cz/cs/10543 (Retrieved November 2, 2015).

6 The total amount of money $-220,000 \mathrm{CZK}$ (in 2013) - is received over a period ranging from 1,5 years to 4 years, according to the parents' choice (with certain limits). The "standard model", i.e. 30 months (up to the child's third birthday) provides a level of parental allowance of 7,300 CZK per month which represented around $30 \%$ of the average monthly gross wage in 2013 (VÚPSV 2014: 15). 
parenthood with paid work. Similar to other scholars (Thompson, Lee and Adams 2013), the author believed that the strategy of choosing future parents rather than those who already had a child would make the identification of cultural norms and ideals easier.

By means of semi-structured interviews, expectant parental couples were questioned on their plans and ideas with respect to parenthood. The research was conducted as part of the international longitudinal project TransPARENT which aimed to compare the transition to parenthood in different European countries (Grunow and Evertsson 2016). ${ }^{7}$ A total of 32 in-depth interviews were conducted by two interviewers ${ }^{8}$ between October 2011 and April 2012. Interviewees were questioned on their everyday lives with an emphasis on employment, housework and leisure-time activities, as well as on their plans and hopes for the period following the birth. The various topics were raised repeatedly during the interviews in order to follow differing timelines: the previous situation (when the couple began to cohabit), the current situation (during pregnancy), plans for the first few weeks following the birth, plans for when the child reaches one and a half years old, and long-term plans (life in three years' time, and beyond).

The aim of the interviews was to determine the views of couples who lived together and expected their first child within six months or less, who both worked (either employed or selfemployed) and who had similar levels of (relatively high) educational attainment. Respondents were recruited via the use of the interviewers' social networks and by approaching expectant mothers in gynaecologist waiting rooms and those attending exercise courses for pregnant women. All but two interviews were conducted in the homes of the respondents and each participant was interviewed separately so as to ensure that answers were not influenced by the presence of the partner. The average length of the recorded interviews was roughly one hour (61 minutes).

The sample was selected according to purposive sampling with respect to the international design of the project. Firstly, due to the study's interest in the combination of parenthood and paid work, only dual-earner couples were included in the sample. Secondly, couples of expectant parents with similar and relatively high levels of education and earnings were preferred. It was believed that such couples were better placed financially to eventually choose from various forms of childcare. It is important to mention here that most participants lived in regions with the lowest unemployment rates (less than $5 \%$ ) and the highest income levels in the Czech Republic. The educational level of most participants was high, as was their income, and in the case of seven couples the woman's wage was higher than that of the man. Eleven of the couples were married and the other five did not plan to marry before their child was born. ${ }^{9}$ Ten couples lived in Prague or the city's suburbs, five in the South Bohemia region and one in Pilsen. Of the total of 32 participants, 19 had completed college education, 7 secondary education with the secondary school leaving certificate and 6 vocational secondary

7 For more information about the research project see http://www.transparent-project.com.

8 The author and R. Stuchlá, whose assistance the author would like to particularly acknowledge.

9 This roughly corresponds to the average for the country, i.e. around $40 \%$ of children were born out of wedlock in 2010. The highest proportion of such children is born to poorer and less educated mothers (Hamplová 2007; Rychtaříková 2013). 
education without the leaving certificate (GCSE exam). The oldest respondent was 35 years of age and the youngest 21 . The mean age of the sample was 28 for women and 29 for men. ${ }^{10}$

All the interviews were recorded and subsequently transcribed. The transcribed data was coded and analysed with the help of ATLAS.ti. Open coding and categorisation according to subject was followed in the next stage by axial coding; qualitative content analysis was employed. During the analysis process, plans regarding childcare and combining parenthood with paid work were extracted from the interviews for each interviewee separately and, on the basis thereof, distinct plans were described for both fathers and mothers. In the next stage the unit of analysis was changed from individuals to the (parental) couple. Only then was the identification of different care models possible, as was the tracing of intra-couple differences with regard to parenting plans.

With regard to ethical issues, all participants provided informed consent to the recording of the interviews. They were promised that the data would not be used in relation with their names, which led the author to use alternative names in this study; the given names of the woman and man in each couple begin with the same letters.

\section{Reconciling parenting and paid work}

Interviewee plans for combining early parenthood with work life were clearly influenced by their knowledge of the various legal options open to them and the afore-mentioned maternity and parental leave entitlement.

\section{The plans of expectant fathers}

The plans of the men interviewed with regard to the first three years of parenthood and employment were clear and unanimous in one respect, namely that all of them expected to continue to work full time. None of the male respondents planned to claim either maternity leave or parental leave. Only a minority of respondents mentioned this option in passing. Indeed, it is significant that the male interviewees (as well as many female interviewees) tend to refer to parental leave as maternity leave. This is most likely due to historical reasons (parental leave was called "following maternity leave" up to 1990) as well as the fact that it is overwhelmingly seen as a measure designed exclusively for mothers. Many of the men interviewed argued that it is simply "natural" for a woman to stay at home with the child. For some couples, the man taking parental leave was totally out of the question.

Me take maternity leave? This did cross my mind but I think it is more suitable for the mother. Well, I don't know, shouldn't the mother do it? As I say, it is the mother's role. To be honest, I have never heard from my friends (male) that a man might take maternity leave. Yet again, if the two agree and prefer it that way why not? I am not sure how it works but it seems to me that the mother always stays at home and the man should earn the money. (Miroslav, car mechanic)

10 The mean age of Czech first-time mothers at birth was 27.9 in 2012 (Štyglerová and Němečková 2013). 
How did interviewed expectant fathers plan to balance their professional lives with family responsibilities? Although they did not anticipate any radical changes as far as work was concerned, many of them realised to what extent their work might be affected by childbirth. A large number of expectant fathers talked about modifying their working hours or even completely changing jobs. Some intended to work extra hours to better provide for the family while others wanted to reduce their workload and overtime in order to spend more time with the family. None of them planned to work part time only.

The first strategy aimed at reconciling work and family life anticipated by the expectant fathers consisted of reducing their workload or ceasing to work at less socially acceptable times such as evenings. However, the intended reduction in working hours in practice usually meant adjusting to regular full-time employment working hours (i.e. 40 hours per week). University-educated men with higher incomes particularly mentioned that they would attempt to reduce their working hours in order to spend time with the baby. It was clear that they were aware of the "involved father" model (Burgess 1997; Klinth 2008; Parke 1996) and intended to fulfil it at least to some extent.

The opposite strategy was anticipated by the limited number of prospective fathers in the sample with lower incomes and education levels. They considered childbirth a reason to spend more time at work in order to increase their earnings. They planned that providing for their families' needs would make up a central element of their parental role, at least during the time when the family income was reduced due to the mother's periods of maternity and parental leave. Due to the small sample size and the low rate of participation of men/ couples on low incomes and with a low educational background, the author is unable to prove whether this relationship is significant for the parental population. Further research is required to provide a more detailed explanation of the relationship between the stronger breadwinner role and increasing work load and the issue of the father's income with reference to lower income and lower educated men/couples.

All the interviewed future fathers considered it normal that they would continue to work full time so as to provide for their families. In a way similar to that in neighbouring Germany, as revealed by Ostner (2002), the father-breadwinner norm persists in Czech society and was, to a greater or lesser extent, explicitly present in all the men's expectations of their primary parental role, at least for the first three years. However, the strategies and priorities of the men in the sample differed. Some of the expectant fathers - all of them highly educated - stressed the importance of spending time with their child and partner and therefore planned to decrease their working hours. Others, however - considerably more often those with lower incomes and lower levels of educational attainment - favoured more traditional roles and stressed the male responsibility as provider, which in fact meant working longer hours so as to earn more money for their families. In some cases both strategies involved changing jobs or seeking promotion.

\section{The plans of expectant mothers}

Whilst all of the men's plans concerned ways to balance their professional lives with family responsibilities, those of the women attempted to reconcile childcare and housework with 
potential employment. Thus, their starting position was markedly different; the expectant mothers were about to accept a new obligation and accord it priority over all other aspects of their lives, including their jobs - to which, up to that point, they had devoted a significant amount of their time.

All the women interviewed planned to take maternity leave to the maximum of 28 weeks. The overwhelming majority of those sampled planned to subsequently take up parental leave, and only two expected a quick return to work without claiming parental leave. Many women respondents stated that they trusted their partners with concern to childcare; however, they felt that it would make life more complicated if the man were to take parental leave. Indeed, the women respondents were, on the whole, reluctant to shift part of the parental leave entitlement to their partners. ${ }^{11}$ They felt that their partners would look after the child but neglect the household chores. This commonly formed part of the construction employed by the women respondents to justify their taking parental leave rather than the father.

I think that even if the man stayed at home with the child, he wouldn't manage all that a woman wants to get in exchange. I feel that I would go to work and still have to make sure a lot of things get done after I get home. So I think this kind of wouldn't work out. (Hana, financial advisor)

Slightly more interviewees planned to claim parental allowance up to the child reaching three years of age than those who expected to claim up to the child's second birthday. However, many expectant mothers in the research sample were planning some kind of parttime or irregular work while claiming parental allowance. They differed both in terms of the anticipated point at which they would return to work, i.e. between six weeks and two years following childbirth, as well as in the form such work would take - some anticipated working from home, others working outside the home. Those women whose jobs before childbirth were more flexible in terms of hours and location were more likely to consider an early return to work. However, all of them emphasised reconciliation between work and family and distanced themselves from "careerism" at the expense of their maternal role and relationship with the child. Those anticipating employment before the child's second birthday were mostly planning to work when the child was sleeping or supervised by close family members (mainly fathers and grandmothers).

Only a minority of interviewed expectant mothers supposed that they would not work for their employer during the three-year period of parental leave. They intended to devote themselves fully to their children and, at the same time, did not expect to be offered a job which would meet their needs, i.e. a job with a combination of good pay and flexible or suitable time requirements.

To sum up, many mothers had plans to work part time during the three years following the birth of their child. Even the ideas of those who planned to start to work early (in the baby's first year) were somewhat vague with regard to specific arrangements for the care of the baby by someone else and the amount of time they would spend at work.

11 Women's unwillingness to shift part of the parental leave entitlement to men was previously reported by Nešporová (2005: 22-23); a similar situation has been described in Germany (Ostner 2002: 164). 
They stressed that they would prioritise adapting their work lives to the needs of their child at the expense of advancing their careers and making money. The general attitude appears to be that motherhood means primarily caring for the child and, if the child is fine and other conditions allow it, the mother can also work in the first three years, most commonly part time.

\section{Different care models and intra-couple differences}

Three basic care models were identified on the basis of the interviews, in terms of the couples' plans concerning childcare and the reconciliation of the parental role with paid work. It is significant that women's plans differed more than those of the men; therefore, even though the study compares the different plans of the couples, the identification of care models was based primarily on different ideas regarding women and the combination of care and work. This is due simply to the fact that all the men in the sample planned to continue fulltime work following the birth of the child. In the first model, the mother planned to fully care for the baby until her/his third birthday; in the second model, the mother considered part-time work before the child's third birthday; and in the third model, the mother planned a quick return to work (part time) without claiming parental leave.

\section{The long-term full-time mothercare model}

In the first model - the long-term full-time mother care model - the mother planned to take the maximum amount of maternity and parental leave, i.e. up to the child's third birthday; and the father planned to continue full-time work. This was the plan for about one third of the interviewed couples, who differed considerably in terms of education, income and profession. These couples had also varying opinions on the father's involvement in childcare. Even though they planned to adopt a model in which the man would be the main breadwinner, with the woman caring for the baby for up to three years, a number of them planned to involve the father in childcare and housework as much as possible, taking into account his work obligations.

I expect that he (the husband) will support us (me and the baby). I cannot specify right now what that support will be - it's too early for that. But I know that fathers often return home and bathe the baby; this is common, as is putting the baby to bed which is mostly done by fathers. I would be very happy to have it this way.... As for changing nappies, he will have to do it... I want him to be able to care for the baby, for instance for a week, that is, to be able to stay with him/her at home on his own; to be able to do everything. Okay, this depends on his work obligations allowing him to do it. (Edita, IT project manager)

\section{The long-term part-time mothercare model}

Half of the interviewed couples anticipated to practice the long-term part-time mother care model. This model involved the father continuing to work full time and the mother caring for the baby for three years whilst simultaneously working part time. The couples differed 
in terms of the emphasis placed on the mother performing paid work. It was significant that in the interviews more women than men (referring to their partners' plans) mentioned that they would like to start (part-time) work earlier than their child's third birthday. Some of the plans were vague while others were relatively specific in terms of the amount and timing of work and childcare arrangements.

The women were usually quite open to the idea that they would start part-time or irregular work while their child was still less than three years old. However, it should be mentioned here that part-time positions are rare in the Czech Republic and are offered by very few businesses (Bartoňová and Nývlt 2011). Many employers consider part-time employment uneconomical due to burdens in terms of management and administrative and material costs. Moreover, flexible forms of work that help to reconcile work with childcare remain few and far between in the Czech Republic (Křížková and Vohlídalová 2008: 100; Kyzlinková and Svobodová 2007; Sokačová 2006).

The intra-couple comparative analysis revealed that the idea of the woman working before the end of the maximum formal parental leave period originated predominantly with the female not the male partner. At the same time, the female partner was expected to manage childcare while working.

It is striking that in some interviews the men did not mention their partner's intention to work, which might be interpreted as a tendency for more segregated gender roles in those couples. In those cases, the male partner assumed the role of breadwinner and did not expect his partner to engage in paid work during the maternity and parental leave periods. From one point of view this might be considered in a positive light, e.g. that the man does not wish to force his partner to work; conversely, however, it leads to a number of serious constraints. Such men most probably had no intention of supporting their partner in arranging for childcare in order for the mother to work; at least, such support was only rarely mentioned in the interviews. One extreme case involved a self-employed couple, hairdresser Iveta and her husband Ivan, a painter. Iveta planned a quick return to work, describing this as essential for her business. In order not to risk losing her clients she intended to start working again six weeks after childbirth for a few hours a week, gradually increasing her hours so that she would be working around three mornings per week when the child reached the age of one and a half years. Even though Iveta claimed that she had discussed this plan with her husband, he did not mention it during the interview (not even when he was directly asked about it) and simply stated that his partner intended to take parental leave up to the child's third birthday.

When considering childcare plans when the mother planned to work, most couples supposed other family members would look after the child, usually the father and grandmothers. The potential use of institutional daily childcare was mentioned only rarely and only after the child reached two years and older. While a number of women were clear in their intention to work part time, they had very vague ideas concerning childcare. Some of the respondents from the couples who planned to apply the long-term part-time mother care model rejected the idea of institutional childcare, nannies and even regular childcare provided by grandparents or the father of the child. In such cases, the woman hoped that she would be able to manage both obligations at the same time, for instance when the baby was sleeping. Diana, a training manager, expressed the wish to start work as soon as six 
weeks after childbirth for around two hours, five times a week from home, and, following the maternity leave period, she planned to increase her workload to two days a week up to the child reaching three years of age. At the same time she stated that:

I do not want my working to be at the expense of the baby, to arrange babysitting. Even though I know that I could ask a grandmother to care for her/him and I am sure the level of care would be more than adequate, I do not feel that the grandmother should perform the function of mother at that time (during parental leave). (Diana, training manager)

The main role (or "function", as Diana referred to it) of the mother was seen as caring full time for the child for the first three years of her/his life. Later, Diana also stated that she and her husband did not want to use institutional care for the baby before the age of three years. This case clearly illustrates a clash between the normative ideal of intensive mothering (i.e. the nurturing and unselfish mother responsible primarily for child rearing) and plans to continue with a career and to engage in paid work. Such cultural contradictions are common in contemporary societies, as was argued by Hays (1996), who first described the ideology of intensive mothering and traced its evolution.

How does Diana intend to combine work and childcare without the support of other persons or institutions? Even though her case was extreme compared to the other couples planning to use this care model, she was not alone in not having precise ideas on managing childcare and paid work. In Diana's case, the intra-couple discrepancies were strong. The inconsistencies in her plans can be better understood in light of her partner's attitudes. He was strongly opposed to any kind of non-parental care whilst, at the same time, being unwilling to care for their child in order to allow his partner to work.

\section{The short-term mothercare model}

The short-term mother care model was characterised by a clear intention on the part of the mother to return to work quickly and not to take advantage of parental leave. Even though expectant fathers in such couples planned to continue full-time work, they sympathised with their partners and were willing to assist in childcare so as to make it possible for them to work. The reason for these women returning quickly to work was that they simply enjoyed their work. At the same time, they stated that they would not hesitate to trust their child to the care of others, such as the father, grandparents and potentially outside nannies and institutions, even in the child's first year. Only two couples in the sample chose this care model; in both cases, the woman earned an above-average salary and had a significantly higher income than her male partner. Education levels were the same in both couples; the partners in one couple had completed tertiary education and in the second couple both had the secondary school leaving certificate.

Even though couples opting for the short-term care model had clear ideas about the division of childcare between the parents and the use of non-parental care, they remained, on the whole, reluctant to use non-family childcare. Nevertheless, female interviewees were significantly more open to the use of non-family childcare than their male partners. For instance, financial advisor Hana stated that she was thinking about hiring a nanny to work for 
her for around two days per week; however, her husband was strongly against this. He felt they could manage childcare with the help of grandmothers and other family members:

My wife got the idea that we could have a nanny or something like that, but I said to myself, no way! We have so many family members on my wife's side and mine that if we need someone to look after the child there will always be someone available. (Hans, construction worker)

Therefore, his wife Hana agreed with her mother that she would care for the child for two or three hours a day in her office, on the condition that the child was well-behaved, thus allowing Hana to pursue her professional activities. In addition, she planned that her husband would care for the baby for a few hours in the afternoon when he returned from work.

$* * *$

When one looks at expectant couples as specific units, it is evident that all the partners agreed on the idea that the mother would assume the responsibility of childcare while the father worked and provided money for the family. Nevertheless, no matter which care model they planned to apply, a number of slight discrepancies existed between the plans of the expectant fathers and mothers. The most common difference with regard to combining work and childcare was the fact that female interviewees more often than their male partners mentioned the possibility that they might work (part time) before the end of the maximum period of parental leave. A comparison of partners within the couples revealed that some women were more likely to favour entrusting the child to non-parental care than their partners, who either rejected the idea out of hand or did not mention it at all.

\section{Disc ussion and conclusions}

Interviewees used norms and values which they considered appropriate, and for many of them the most important point of reference consisted of the experiences of their friends and work colleagues. It was clear from the interviews that their plans for and notions of approaching parenthood were not at all fixed. Women's plans, particularly concerning combining childcare and work, were often no more than provisional. The expectant mothers knew that things might change and they were prepared to adjust their plans to the needs of the child. Thus, the interviews said more about cultural norms and general ideas than about real situations the respondents are likely to face once they become parents. This is in line with the findings revealed by the longitudinal life course approach (Smart and Neale 2002).

\section{The norms of intensive motherhood and breadwinner fatherhood}

This study of the working and caring plans of expectant fathers and mothers revealed that maternity and paternity were conceptualised very differently within the sample group. The traditional model of complementary roles, according to which the mother is responsible for childcare and takes parental leave, while the father works and is the main financial provider for the family, very much predominated. It is possible to refer to such normative 
ideas as the norm of intensive (full-time) motherhood accompanied by that of breadwinner fatherhood. Nevertheless, a significant number of interviewees expressed their plans or wishes to challenge this model to some degree. The women planned to act as primary care providers for the first three years but, at the same time, many of them expected that they might engage in paid employment at the same time. Moreover, many men and their female partners hoped that the father would get involved in childcare in his free time. From this point, we could talk about neo-traditional parental roles (Blankenhorn 1995; Popenoe 1996), where the main division stays fixed to father breadwinner and mother caregiver, while it is possible (or even desirable) to go past the boundaries partly, provided that it does not endanger the given order. This means that the mother should not spend more time in paid work than the father, and the father should not care for the baby more than the mother does. Nevertheless, the maternal role involving caring for the child and home for the first three years rather than taking on paid work predominated. The Czech norm of "the right-thinking, caring mother", according to which the mother stays at home and fully cares for her child over his or her first (three) years, was described by Hašková and Zamykalová (2006) ten years ago. This research confirmed that this norm is still very much valid, as was made clear from the interviews with expectant parents.

Nevertheless, most of the women in the sample anticipated starting work before the child's third birthday. Working and childcare were not regarded as irreconcilable by the interviewees; indeed, this partly reflects the formal possibility of working while claiming parental allowance. The author therefore poses the following questions: What kind of work was seen as reconcilable with motherhood? And what kind of work was viewed as irreconcilable with the first three years of motherhood?

Firstly, the mother's paid work would take second place to childcare; female respondents, especially those with higher levels of education who planned a quick return to paid employment (during the child's first year), stressed that their plans would not be in conflict with their child's best interests. Moreover, the female respondents were keen to emphasise that they do not consider themselves to be "careerist". The clear message is that if a mother returns to paid employment before the child reaches three years of age (the end of parental leave), it must not be at the expense of caring for the child, which was the overriding consideration.

Why was career perceived so negatively in relation to motherhood? The author would argue that the idea of paid work violates the core concept of intensive motherhood in which the child comes first and represents the principal interest of the mother. A clear difference emerged between performing standard work, i.e. having a job and forging a career, which was seen as threatening the interests of the child, and is therefore undesirable and irreconcilable with motherhood.

On the other hand, the mother could work during parental leave provided the interest of the child was not endangered. In some cases, analysis revealed that it was important that the mother's paid work was seen as supplementary to that of the father. Most of the mothersto-be planned to work only part time as opposed to their partner's full-time employment. Such plans clearly follow the cultural norm which sees the father as the main breadwinner. This mechanism, whereby the woman's financial contribution to the family budget is played 
down, has been described previously by other Czech scholars (Maříková 2012). It should be stressed that this attitude was also characteristic of those couples in which the woman's income exceeded that of the man before the commencement of maternity leave. From this point of view, the study proved the theory that parenthood is essential in the process of doing gender (West and Zimmerman 1987) and, in this case, it supports the creation of a gender order featuring complementary parental roles.

The author would argue that the norm of intensive motherhood, or the full-time caring mother, was, in the Czech case, strongly supported by structural circumstances. Firstly, the "standard" length of parental leave has been promoted by the Ministry of Labour and Social Affairs over the last few years as lasting up to the child's third birthday. Secondly, from 1990 to 2004 parental allowance was provided to full-time caring parents, i.e. employment was limited by the setting of a very low cap on the amount of extra income which a parent could earn while receiving the allowance. Thirdly, from 1990 to 2014 parental allowance was provided only to full-time caring parents whose child had limited access to public childcare. ${ }^{12}$ And fourthly, public childcare facilities for children younger than three years of age are very rare due to the closure of a large number of such institutions from 1990 onwards (Kuchařová and Svobodová 2006; Saxonberg and Szelewa 2007).

\section{The intra-couple discrepancy and tensions between norms}

The intra-couple discrepancy mentioned above, i.e. the expectant father not mentioning his partner's work plans, might, in some cases, be interpreted as a way to stress the breadwinner role of the father compared to the caring role of the mother. Other male interviewees always referred to their partners' plans to work during the first year of the child's life with respect, but never as more important than their work and income. It was obvious that even those couples intending to challenge the traditional gender order employed discourses and norms which are commonly shared in society. This phenomenon has been described previously in the context of other aspects of parenthood with respect to distinct groups, including lesbian mothers and childless women (Hašková and Zamykalová 2006; Nedbálková 2011). According to this mechanism, interviewees use certain ideas and notions which they expect are widely shared norms as a reference point and either try to converge with such notions or specify in which respect they wish to differ from them. However, the research presented here did not focus on distinct groups going against such norms (such as lesbian mothers or intentionally childless women); therefore, the expectant parents interviewed mostly aligned themselves with common norms and did not distance themselves from them. Armed with this knowledge, the plan commonly presented by expectant mothers to work part-time before their child reaches the age of three years indicates that the norm of three years of fulltime motherhood is losing its normative strength.

12 This restriction has been of less relevance since 2008, since which time parents with average and higher incomes have been able to choose a shorter period of parental allowance, i.e. up to the child's second birthday. 
At this point, the author would like to stress the discovery of a common discrepancy between expectant fathers and mothers in terms of planning work and care arrangements following the birth of their child. While pregnant women often expressed the expectation of returning to their previous employment position within two years of the birth, their male partners in many cases failed to mention this eventuality. Moreover, men tended to refuse to consider non-family childcare during the initial (three) years of their child's life more frequently than did their female partners. Hence, clearly this group of women consisted of those prepared to challenge the norm of the full-time caring mother. Conversely, most of the expectant fathers appeared to conform to the traditional gender order which assumes segregated gender roles and considers the breadwinner role as the norm. Notably, none of the male respondents challenged this role during the interviews.

A degree of tension between the intensive full-time motherhood norm and the plans of the women to work was apparent from analysis of the interviews (cf. Hays 1996). A comparison of the couples revealed that the view of the fathers was an important influence on the mothers' plans regarding combining childcare and paid work. The shortterm mother care model was seen as much more credible in cases where the man was open to the idea of the mother working and non-maternal childcare. Conversely, the long-term mother care model predominated in cases where the father strongly identified with the role of breadwinner and the mother with that of caregiver. However, even in many cases where the couples planned to adopt the long-term part-time mother care model, it was unclear who would look after the child when the mother planned to work. Parental care was generally considered the best option during a child's early years. At the same time, it was conceded that the father's availability for this task would be limited by his work. Moreover, the father often expressed his unwillingness to care for the child while his partner worked. In addition, it was recognised that securing appropriate non-parental care would be difficult. Not only is such care often simply unavailable due to appertaining structural conditions and a lack of nurseries, but parents, fathers especially, were generally reluctant to make use of such services.

\section{More support needed for employed mothers and fathers}

It is a question, therefore, to what extent, if at all, the interviewed expectant mothers will be able to fulfil their plans for paid employment in the first few years following the birth of their child. Clearly, if the state prefers mothers to work, it should seriously consider supporting more favourable conditions for them to realise their plans. Firstly, there should be greater support for the provision of institutional or other non-parental childcare for children younger than three years of age. Secondly, employers should be given greater motivation to offer more flexible working conditions as well as part-time positions. Thirdly, incentives should be created for fathers to become more involved in parenting which, in turn, would lift part of the burden placed on mothers in a society in which parental care is generally considered the best childcare option during a child's early years. 


\section{References}

BARTÁKOVÁ, Helena. 2005. “Znevýhodnění žen s dětmi na trhu práce.” [Disadvantagement of Women with Children in the Labour Market]. Pp. 65-77 in Účelové programy na lokálních trzích: Jejich význam, potřebnost a realizace [Specific Local Employment Programmes. Their Meaning, Needs and Realization], edited by Jiří WINKLER, Lenka KLIMPLOVÁ and Martin ŽIŽLAVSKÝ. Brno: Masaryk University.

BARTOŇOVÁ, Dagmar and Ondřej NÝVLT. 2011. "Rodinné domácnosti na trhu práce: Vývoj ekonomické aktivity matek a otců z hlediska věku dětí." [Family Households in the Labour Market: The Economic Activities of Mothers and Fathers by the Age of Their Children]. Demografie 53(3): 215-222.

BLANKENHORN, David. 1995. Fatherless America: Confronting Our Most Urgent Social Problem. New York: Basic Books.

CROMPTON, Rosemary and Fiona HARRIS. 1998. "Explaining Women's Employment Patterns: 'Orientations to Work' Revisited." The British Journal of Sociology 49(1): 118-136.

CROMPTON, Rosemary and Clare LYONETTE. 2005. "The New Gender Essentialism - Domestic and Family 'Choices' and Their Relation to Attitudes." The British Journal of Sociology 56(4): 601-620.

CROMPTON, Rosemary and Clare LYONETTE. 2011. "Women's Career Success and Worklife Adaptations in the Accountancy and Medical Professions in Britain." Gender, Work and Organization 18(2): 231-254.

ČERMÁKOVÁ, Marie et al. 2002. Podmínky harmonizace práce a rodiny věeské společnosti [Conditions of Harmonization of Work and Family in the Czech Republic]. Prague: Sociologický ústav AV ČR.

DUDOVÁ, Radka. 2006. "Rozporuplné diskursy otcovství." [Contradictory Discourses of Fatherhood]. Gender, rovné přiležitosti, výzkum 7(2): 6-10.

DUDOVÁ, Radka. 2008. Otcovství po rozchodu rodičovského páru [Fatherhood after Parental Separation]. Prague: Sociologický ústav AV ČR.

DUNCAN, Simon and Rosalind EDWARDS. 1999. Lone Mothers, Paid Work and Gendered Moral Rationalities. London: Macmillan.

DUNCAN, Simon, Rosalind EDWARDS and Pam ALLDRED. 2003. "Mothers and Child Care: Policies, Values and Theories." Children \& Society 18(4): 254-265.

DUNCAN, Simon and Sarah IRWIN. 2004. "The Social Patterning of Values and Rationalities: Mothers' Choices in Combining Caring and Employment." Social Policy and Society 3(4): 391-399.

ETTLEROVÁ, Sylva et al. 2006. Postoje a zkušenosti s harmonizací rodiny a zaměstnání rodičủ dětí předškolniho a mladšiho školního věku [Attitudes and Experiences with Harmonisation of Family and Employment of Parents with Pre-school and School-age Children]. Prague: Výzkumný ústav práce a sociálních věcí.

GRUNOW, Daniela and Marie EVERTSSON. 2016. Couples'Transitions to Parenthood. Analysing Gender and Work in Europe. Cheltenham: Edward Elgar.

HAMPlOVÁ, Dana (ed.). 2007. Děti na psí knížku? Mimomanželská plodnost v České republice [Out-of-wedlock Children? Non-marital Fertility in the Czech Republic]. Prague: Sociologický ústav AV ČR.

HAŠKOVÁ, Hana and Steven SAXONBERG (eds.). 2012. Péče o nejmenši: Boření mýtů [Early Child Care: Myth Busted]. Prague: Sociologické nakladatelství.

HAŠKOVÁ, Hana and Zuzana UHDE. 2009. Women and Social Citizenship in Czech Society: Continuity and Change. Prague: Sociologický ústav AV ČR.

HAŠKOVÁ, Hana and Lenka ZAMYKALOVÁ. 2006. "Mít děti - co je to za normu? Č́ je to norma?" [Having Children - What Norm It Is? Whose Norm It Is?]. Biograf 13(40-41): 3-53. 
HAYS, Sharon. 1996. The Cultural Contradictions of Motherhood. New Haven: Yale University Press. KUCHAŘOVÁ, Věra et al. 2006. Zaměstnání a péče o malé z perspektivy rodičů a zaměstnavatelů [Employment and Child Care from the Perspective of Parents and Employers]. Prague: Výzkumný ústav práce a sociálních věcí.

KUCHAŘOVÁ, Věra and Kamila SVOBODOVÁ. 2006. Sit’ zařizeni denní péče o děti předškolního věku v $\check{C} R$ [Network of Child-care Services for Pre-school Children in the Czech Republic]. Prague: Výzkumný ústav práce a sociálních věcí.

KŘÍŽKOVÁ, Alena (ed.). 2006. Pracovni a rodinné role a jejich kombinace v životě českých rodičů: plány versus realita [Working and Family Roles and Their Combination in the Life of Czech Parents: Plans versus Reality]. Prague: Sociologický ústav AV ČR.

KŘÍŽKOVÁ, Alena et al. 2009. "The Conditions of Parenthood in Organisations: An International Comparison.” Sociologický časopis/Czech Sociological Review 45(3): 519-547.

KŘÍŽKOVÁ, Alena et al. 2011. Pracovni dráhy žen v České republice [Working Paths of Woman in the Czech Republic]. Prague: Sociologické nakladatelství.

KŘÍŽKOVÁ, Alena and Marta VOHLÍDALOVÁ. 2008. "Kdo se bojí zaměstnané matky?” [Who is Afraid of Working Mother?]. Pp. 85-105 in Práce a péče [Work and Care], edited by Alena KŘÍŽKOVÁ et al. Prague: Sociologické nakladatelství.

KŘÍŽKOVÁ, Alena and Marta VOHLÍDALOVÁ. 2009. "Rodiče na trhu práce: mezi prací a péćí." [Parents in the Labor Market: Between Work and Care]. Sociologický časopis/Czech Sociological Review 45(1): 31-60.

KYZLINKOVÁ, Renata and Kamila SVOBODOVÁ. 2007. "Práce z domova a její zásah do rodinného života.” [Working from Home and Its Intervention into Family Life]. Fórum sociálni politiky 1(1): $11-17$.

MǍ̌íKOVÁ, Hana. 2008. “Caring Fathers and Gender (In)Equality?” Polish Sociological Review 48(162): 135-152.

MAŘÍKOVÁ, Hana. 2009. "Pečující otcové: Příběhy plné odlišnosti.” [Caring Fathers: Stories Full of Diversity]. Sociologický časopis/Czech Sociological Review 45(1): 80-113.

MAŘÍKOVÁ, Hana (ed.). 2012. Živitelé a živitelky: reflexe (a) praxe [Male and Female Breadwinners: Practice and Reflections]. Prague: Sociologické nakladatelství.

MAŘíKOVÁ, Hana and Marta VOHLÍDALOVÁ. 2007. Trvalá nebo dočasná změna? Uspořádání genderových rolí v rodinách s pečujícími otci [A Permanent or Temporary Change? The Arrangement of Gender Roles in Families with Caring Fathers]. Prague: Sociologický ústav AV ČR.

MILLER, Tina. 2007. “'Is This What Motherhood is All About?' Weaving Experiences and Discourse through Transition to First-Time Motherhood.” Gender \& Society 21(3): 337-358.

NEDBÁLKOVÁ, Kateřina. 2011. Matky kuráže: lesbické rodiny v pozdně moderní společnosti [Mothers of Courage: Lesbian Families in the Late Modern Society]. Brno: Sociologické nakladatelství and Masaryk University.

NEŠPOROVÁ, Olga. 2005. Harmonizace rodiny a zaměstnání: Rodiny s otci na rodičovské dovolené [Harmonization of Family and Job: Families with Father on Parental Leave]. Prague: Výzkumný ústav práce a sociálních věcí.

NEŠPOROVÁ, Olga. 2006. "Otcové pečující o děti formou rodičovské dovolené." [Fathers Caring for Children in the Form of Parental Leave]. Demografie 48(3): 179-193.

NEŠPOROVÁ, Olga. 2015. "Flexibilní režim čerpání rodičovského příspěvku a slad’ování rodičovství s placenou prací." [The Flexible Parental Benefits System and the Reconciling of Parenthood with Paid Work]. Fórum sociální politiky 9(6): 10-18.

OSTNER, Ilona. 2002. "A New Role for Fathers? The German Case”. Pp. 150-167 in Making Men into Fathers, edited by Barbara HOBSON. Cambridge: Cambridge University Press. 
PALONCYOVÁ, Jana et al. 2013. Systém denni péče o děti do 6 let ve Francii a v České republice [Daily Care System for Children below 6 Years in France and the Czech Republic]. Prague: Výzkumný ústav práce a sociálních věcí.

PALONCYOVÁ, Jana et al. 2014. Nové formy denni péče o děti v České republice [New Forms of Daily Care for Children in the Czech Republic]. Prague: Výzkumný ústav práce a sociálních věcí.

PARKE, Ross D. 1996. Fatherhood. Cambridge, MA: Harvard University Press.

POPENOE, David. 1996. Life without Father: Compelling New Evidence that Fatherhood and Marriage are Indispensable for the Good of Children and Society. Cambridge, MA: Harvard University Press.

RYCHTAŘÍKOVÁ, Jitka. 2013. "Děti narozené v manželství a mimo manželství: dvě různé populace." [Two Different Populations: Children Born in and out of Wedlock]. Demografie 55(1): 4-26.

SAXONBERG, Steven and Tomáš SIROVÁTKA. 2006. "Failing Family Policy in Post-communist Central Europe." Journal of Comparative Policy Analysis: Research and Practice 8(2): 185-202.

SAXONBERG, Steven and Dorota SZELEWA. 2007. "The Continuing Legacy of the Communist Legacy? The Development of Family Policies in Poland and the Czech Republic." Social Politics 14(3): 351-379.

SIROVÁTKA, Tomáš. 2004. "Family Policy in the Czech Republic after 1989: From Gendered and Enforced De-Familialism to Gendered and Implicit Familialism.” Pp. 97-117 in Society, Reproduction and Contemporary Challenges, edited by Petr MAREŠ. Brno: Barrister \& Principal.

SMART, Carol and Bren NEALE. 2002. "Caring, Earning and Changing: Parenthood and Employment after Divorce.” Pp. 183-198 in Analysing Families: Morality and Rationality in Policy and Practice, edited by Alan CARLING, Simon DUNCAN and Rosalind EDWARDS. London: Routledge.

SOKAČOVÁ, Linda (ed.). 2006. Kariéra, rodina, rovné př́ležitosti: Výzkumy postavení žen a mužu na trhu práce [Career, Family, Equal Opportunities: Studies on Women and Men in the Labour Market]. Prague: Gender Studies.

SUWADA, Katarzyna and Lars PLANTIN. 2014. "On Fatherhood, Masculinities, and Family Policies in Poland and Sweden - a Comparative Study." Polish Sociological Review 4(188): 509-524.

ŠMíDOVÁ, Iva. 2004. "Rodiny, kde pečují otcové." [Families Where Fathers Mother]. Gender, rovné př́ležitosti, výzkum 5(4): 10-12.

ŠMÍDOVÁ, Iva. 2009. "Changing Czech Masculinities? Beyond Environment and Children Friendly Men.” Pp. 193-206 in Intimate Citizenships: Gender, Subjectivity, Politics, edited by Elzbieta H. OLEKSY. London: Routledge.

ŠTYGLEROVÁ, Terezie and Michaela NĚMEČKOVÁ. 2013. "Populační vývoj v České republice v roce 2012.” [Population Development of the Czech Republic in 2012]. Demografie 55(3): 189-207.

THOMPSON, Rachel, Christina LEE and Jon ADAMS. 2013. "Imagining Fatherhood: Young Australian Men's Perspectives on Fathering." International Journal of Men's Health 12(2): 150-165.

VÚPSV. 2014. Bulletin No 29. Vývoj hlavnich ekonomických a sociálních ukazatelů České republiky 1990-2013 [Bulletin No 29. The Development of Main Economic and Social Indicators of the Czech Republic 1990-2013]. Prague: Výzkumný ústav práce a sociálních věcí.

WEST, Candace and Don H. ZIMMERMAN. 1987. "Doing Gender.” Gender \& Society 1(2): 125-151.

\section{Author}

Olga Nešporová is a researcher at the Research Institute for Labour and Social Affairs in Prague. Her research interest focuses on parenthood, combining care and paid work, and family policy. She is also interested in sociology of death.

Contact: olga.nesporova@vupsv.cz 